\title{
The Fundamental Criterion of Liturgical Translation: Valde Utilis Apud Populum
}

\author{
Mario Tomi Subardjo a,1 \\ ${ }^{a}$ Universitas Sanata Dharma Yogyakarta \\ ${ }^{1}$ tomi.mariosj@gmail.com
}

Keywords:

translation, vernacular,

Latin,

liturgy,

language.

\begin{abstract}
Liturgiam Authenticam, the instruction on the use of vernacular languages in the publication of the books of the Roman liturgy, claims to be faithful to the intentions of the liturgical reform of Vatican II, especially to the intention of Sacrosanctum Concilium 36. From the time of the publication of Liturgiam Authenticam, the debates on the liturgical translation have become tangled in the argument of authority or procedural collaboration between Rome and the Bishops' Conference. The publication of the Apostolic Letter Magnum Principium in 2017 has solved this legal problem. This paper argues that the problem of implementing faithfully the intentions of the liturgical reform of the Vatican II regarding the use of vernacular in the liturgy cannot be simplified by implementing only the correct idea of collaboration between the authorities involved in the work of translation. Further, implementation of the correct understanding of the function of language in the work of liturgical translation is a serious challenge. For this reason, there are some important points to consider regarding Liturgiam Authenticam after the publication of Magnum Principium.
\end{abstract}

\section{INTRODUCTION}

Pope Francis issued the Motu Proprio Magnum Principium, on the modification of canon 838 of the Code of Canon Law, on September 3, 2017. One of the most significant changes is the modification of canon $838 \S 3$, which now says:

"Ad Episcoporum Conferentias spectat versiones librorum liturgicorum in linguas vernaculas fideliter et convenienter intra limites definitos accommodatas parare et approbare atque libros liturgicos, pro regionibus ad quas pertinent, post confirmationem Apostolicae Sedis, edere."

This modification makes clear the return to the procedure of preparing the liturgical translation which was intended by Sacrosanctum Concilium (SC) 36. It is the duty of the Episcopal Conferences to prepare, to adapt, and to approve the translation of the liturgical books. We can say that this modifi- 
cation solves the legal problem regarding the correct implementation of SC 36, but, as we know, the problem of liturgical translation is more than merely a problem of procedural collaboration.

The correction of the implementation of SC 36 found in Liturgiam Authenticam (LA) regarding the procedure of approving and confirming a translation is only one matter, though it is certainly important; but there is still another more fundamental correction to be made. The objective of this essay is to show that the problem of implementing faithfully SC 36 cannot be solved simply by restoring correctly SC's idea of collaboration between the authorities involved in the work of translation. To implement fully SC 36, the present instruction on translation, Liturgiam Authenticam, should be corrected not only with regard to procedural matters but also with regard to its understanding of the function of language and translation in the liturgy.

\section{DISCUSSION ON THE VERNACULAR DURING THE COUNCIL}

Avoiding unfounded and superficial readings of, partial acceptance of, and practices that distort the idea of the liturgical reform of Vatican II regarding the argument about the use of vernacular in the liturgy, this part will focus on the process of the formulation of SC 36, especially the first and second paragraphs, in order to understand better the underlying reasons of the fathers of the Council.

Pope John XXIII announced the Second Vatican Council on January 25, 1959. Some months later, on May 17, 1959, Pope John XXIII instituted a preparatory commission for the Council. On June 5, 1960, the same Pope instituted commissions to prepare the schemas of the documents to be presented for discussion at the Council. Among these groups was the Preparatory Commission on the liturgy. Cardinal Gaetano Cicognani, prefect of the Congregation for Rites, was appointed the president of the commission, and Annibale Bugnini became the secretary. The first meeting of this liturgical commission was held on November 12, 1960.

There were 13 sub-commissions under the Preparatory Commission on the liturgy. These sub-commissions were created based on the topics that were going to be discussed in the Council. One of these topics was the use of the vernacular. This was one of the hardest topics to prepare because of the strong campaign for maintaining Latin as the language of the liturgy on the part of the Roman Curia. The plenary session was held on January 11-13, 1962, and the final text of the schema was ready on January 22. This final text of the schema was submitted by Cardinal Cicognani to the General Secretariat of the Council on February 1, 1962. Pope John XXIII appointed Cardinal Arcadio Larraona, the new prefect of the Congregation for Rites, president of the Preparatory Commission on February 22, $1962 .{ }^{2}$

On February 22, 1962, the date when Pope John XXIII appointed Cardinal Larraona as the new president of the Preparatory Commission, the Pope issued an Apostolic Constitution, Veterum Sapientia (VS), on the promotion of the study of Latin. The publication of this document during the preparatory period of the Council, with its rigorous promotion of Latin, was interpreted as an attempt to impede the openness of the Council to the use of the vernacular in the liturgy. VS emphasized the exclusive and privileged nature of Latin as the language of the universal Church. ${ }^{3}$ Latin was proposed 
as the most suitable language for promoting every form of culture for all people because of its neutrality. Latin was considered neutral because it does not favour any one nation, so it should be also the most acceptable to all. Briefly, VS held that Latin is a language which is universal, immutable, and non-vernacular. According to VS, Latin enjoys this privilege because it has been consecrated throughout history. In the words of VS, Latin is the most effective bond between the past and the future. ${ }^{4}$

The preparatory period was over on October 11, 1962, with the opening of the Council. The Preparatory Commissions were replaced by the Conciliar Commissions. Cardinal Larraona was appointed as the president of the Conciliar Commission for the liturgy by John XXIII.

The discussion of the Council fathers began in the first general congregation, which took place on October 22, 1962, a day af- ter the end of the preparatory period. This general congregation continued until December 7, 1962, when the first chapter was approved. Pope John XXIII closed the first session of the Council on December 8, 1962. He passed away on June 3, 1963, during the Council's recess. On September 29, 1963, Pope Paul VI opened the second session of the Council. On October 4, 1963, the relations and votes on every single part of the Constitution began. This work continued from November 15 to 22, 1963. After all of the proposals had been studied by the Conciliar Commission, the schema was ready for the definitive vote on November 22, 1963. There were 2,178 voters. 2,158 voted placet, 19 non placet and 1 did not vote. ${ }^{5}$

The summary of the shift in the formulation of the first and second paragraphs of the final text of SC 36, which speak about the use of Latin and vernacular languages in liturgy, is as follows: ${ }^{6}$

\begin{tabular}{|c|c|c|}
\hline $\begin{array}{l}\text { The text prepared by the } \\
\text { Preparatory Commission }\end{array}$ & $\begin{array}{l}\text { The text presented in the } \\
\text { General Council }\end{array}$ & $\begin{array}{l}\text { The text amended and ap- } \\
\text { proved }\end{array}$ \\
\hline $\begin{array}{l}\text { Latinae linguae usus in } \\
\text { Liturgia occidentali omnino } \\
\text { servandus est. }\end{array}$ & $\begin{array}{l}\text { Latinae linguae usus in Litur- } \\
\text { gia occidentali servetur. }\end{array}$ & $\begin{array}{l}\text { Latinae linguae usus, salvo } \\
\text { particolari iure, in Ritibus lati- } \\
\text { nis servetur. }\end{array}$ \\
\hline $\begin{array}{l}\text { Cum tamen «in non pau- } \\
\text { cis ritibus vulgati sermonis } \\
\text { usurpatio valde utilis apud } \\
\text { populum exsistere» possit, } \\
\text { amplior locus ipsi in Liturgia } \\
\text { tribuatur; imprimis autem in } \\
\text { lectionibus et admonitioni- } \\
\text { bus, in nonnullis orationibus } \\
\text { et cantibus. }\end{array}$ & $\begin{array}{l}\text { Cum tamen «in non paucis } \\
\text { ritibus vulgati sermonis usur- } \\
\text { patio valde utilis apud popu- } \\
\text { lum exsistere» possit, amplior } \\
\text { locus ipsi in Liturgia tribuatur; } \\
\text { imprimis autem in lectionibus } \\
\text { et admonitionibus, in nonnullis } \\
\text { orationibus et cantibus. }\end{array}$ & $\begin{array}{l}\text { Cum tamen, sive in Missa, sive } \\
\text { in Sacramentorum administra- } \\
\text { tione, sive in aliis Liturgiae } \\
\text { partibus, haud raro linguae ver- } \\
\text { naculae usurpatio valde utilis } \\
\text { apud populum exsistere possit, } \\
\text { amplior locus ipsi tribui valeat, } \\
\text { imprimis autem in lectionibus } \\
\text { et admonitionibus, in nonnullis } \\
\text { orationibus et cantibus, iuxta } \\
\text { normas quae de hac re in se- } \\
\text { quentibus capitibus singillatim } \\
\text { statuuntur. }\end{array}$ \\
\hline
\end{tabular}


From the first paragraph in all three columns, it is obvious that the Latin language is still to be preserved in the liturgy. The changes found in the first paragraph are the transformation from Liturgia occidentali to Ritibus latinis and the addition of salvo particolari iure. Regarding the first change, Jungmann explains that the change from "Western liturgy" to "Latin liturgy" was demanded by, among others, the Yugoslav representatives, who asked that consideration be given to the long tradition of celebrating the Roman liturgy in the Slavic language.? The addition of salvo particolari iure was done during the first session of the Council. The addition was made to protect the existing particular laws regarding this matter.

The preservation of Latin can be seen as a via media, since most of the Fathers who spoke on this question wanted to preserve Latin for some parts of the liturgy and in certain circumstances and to introduce more and more the use of the vernacular. ${ }^{8}$ The via media position preserves the use of Latin but, at the same time, opens to the wider use of vernacular. This position gives some interesting reasons why Latin should be conserved, even while the vernacular should be introduced. These four reasons appeared during the discussion on the Schema: 1) Latin is considered the language of the major part of the Church and the sign of unity; 2) Latin is considered an instrument to avoid the problem of favouritism in the regions which have a great diversity of ethnicities and languages; 3 ) in an era of more frequent interaction among people from all over the world, Latin is considered the universal language that can bridge all the differences; 4) Latin is considered an instrument for conserving the treasure of the Church, especially the Latin liturgical prayers and songs. ${ }^{9}$ In addition, there were some propos- als for the application of the via media solution, such as these: that Latin be used for the parts said by the Priest and the vernacular for the people's parts; that the priest would celebrate Mass in Latin during the weekdays and in the vernacular on feasts, except during the consecration prayer; that the use of Latin or the vernacular be based on the particular celebration, Latin being used in the international or multicultural celebrations. ${ }^{10}$

Some of the reasons of those who supported the via media were used, as well, by those who rejected the use of the vernacular in the liturgy. One objection noted the risk of causing a disharmonious situation in a country with many local languages. Latin was defended as the solution for such a situation because of its neutrality. The majority of the fathers thought that the vernacular would be an important means to achieving the active participation of the people in the liturgical celebration. This idea was denied by the supporters of Latin. Those who supported Latin as the only liturgical language in the Latin Rites insisted that active participation could be achieved by other means. The supporters of Latin proposed that, instead of permitting the use of the vernacular as a liturgical language besides Latin, the vernacular be used only as the catechetical language. ${ }^{11}$

Besides the middle way (via media) and the exclusive Latin position, there was also support for the exclusive use of the vernacular. The reason given for this exclusive use of the vernacular was the experience of the primitive Church, which always used the language understood by the people. ${ }^{12}$ Regarding this opinion, Cardinal Tisserant reminded the Council fathers that many languages have had and have rights of citizenship in the Church. ${ }^{13}$ 
Even though the decision made by the Council regarding the liturgical language can be considered to have followed a via media, we can see from the schema that the consideration of the benefit of the vernacular for the people was never changed. The category of valde utilis apud populum is a new perspective that provides a significant foundation for understanding the nature of liturgy itself. This unchanged formulation shows that the category of valde utilis apud populum should be used as the primary criteria in the application of SC in the post-Conciliar documents.

The use of the word "populum" in the Constitution in its relation to the use of vernacular is intended for the inclusion of those who have been so far ignored, the simple people. For that, we can understand that the use of vernacular was formulated in the Constitution (SC 36\$2) not only for some part of the liturgy but for all of it. The change in the final text of the word "tribuatur" to "tribuivaleat" was chosen as a more moderate expression, to avoid the misunderstanding that the Council intended to impose the absolute use of vernacular. ${ }^{14}$

\section{THE FUNDAMENTAL CRITERION}

While the final formulation of SC 36 explicitly says that the Latin language is to be preserved in the Latin rites, the same article humbly recognizes that the wider use of the mother tongue may give great advantage to the people. This recognition should be seen as a significant shift in the understanding of the liturgy itself. This shift happens when the liturgy is understood from the perspective of the involvement of the people.

To understand the shift in the understanding of the nature of liturgy, we should return to the understanding of Mediator Dei
(MD) of liturgy as the work of salvation done by Christ. MD puts the emphasis on the priestly dimension of the person of Christ. From this understanding, MD understands that all the work of salvation is completed as the priestly action of Christ. ${ }^{15}$ In other words, the work of Christ is the act of priesthood, and the Church continues this work of Christ that is the act of His priesthood. This consideration brings a logical consequence that the work of the Church is understood as the continuation of the work of Christ because the Church is directed by the priests. MD understands the nature of liturgy as the action of the priest and the action of the people reunited only because the priest is their representative. ${ }^{16}$ Based on this statement, we can inquire about the role of the people in the liturgical celebration according to MD.

The question of the role of the people in the liturgy raises other fundamental questions: Who is the subject of a liturgical action, and what is the true nature of liturgy? The clue for the answer to these questions lies in the definition of "active participation" in the liturgy, especially in the Eucharistic celebration. What does MD really think of the people's active participation in the Eucharist? MD makes a clear statement that the principal element of the active participation lies in the act of offerre through and together with the priest, even if the encyclical says that the peak of the active participation of the people lies in the communion of the Eucharist. ${ }^{17}$

This narrow understanding of the active participation of the people in the Eucharist found in MD gives an indirect answer regarding the subject of the Eucharist. The people are not the main subject of the celebration, because the way they participate is 
only in the act of offering. This means that "the actor" of the celebration remains only the person the priest. This consideration of MD is consistent with the model of the Eucharistic celebration given in the Missale Romanum 1570 of Pius V. The first phrase of the Ordo Missae of Pius V speaks of "Sacerdos paratus", but the Ordo Missae of Paul VI manifests a significant change, speaking of "Populo congregato". This significant shift after the Council is the fruit of a renewed understanding of the nature of the liturgy. After the Council, the role of the people is understood not only as participating with the subject of the Eucharistic celebration (priest). The participation of the people is not understood only as the act of "offering", as mentioned in MD. The new understanding of active participation demands that the people itself be the subject of the celebration.

What is the consequence of this new understanding of the role of the people in the liturgical celebration, especially in the Eucharist? The people are considered the subject of the celebration which is the celebration of the mystery of God's salvation. The intention of the liturgical celebration is the salvation of the people. The consequence of this intention is the recognition that liturgy is for the sake of the people rather than that the people are for the sake of the liturgy. This belief was expressed also by Cardinal Montini during the conciliar discussion on October 22, 1962: "Liturgia nempe pro hominibus est institute, non homines pro liturgia."18 This statement of Montini is inspired by the words of Jesus himself in Mark $2: 27$.

If the liturgy is considered as a means of the sanctification of men and women, the liturgy should be designed or adjusted ac- cording to the situation of the people who live in a particular time and culture so that the liturgy can be truly fruitful. One of the most powerful guarantees of this fruitfulness of the liturgy for the people is its intelligibility. The liturgy should be intelligible to the people who celebrate the mystery of the salvation of God. This understanding was considered an impetus to the formulation of SC 36, especially with regard to the phrase "valde utilis apud populum", which is the acknowledgment that the liturgy is truly for the sake of the people and not the contrary. The right and the duty of the people's active participation in the liturgical action comes from the recognition of the sacerdotal baptism of all the people of God. That the people are the subject of the liturgical action was well recognized during the discussion on the schema. Based on this consideration, the use of the vernacular was recognized as a great help for the people. Only through intelligible rites and prayers can the people participate actively in the mystery being celebrated.

The criteria of "valde utilis apud populum" as the basis for the wider use of the vernacular in the liturgy can be understood also in the dialectical structure of the human-divine nature of the Church, which is nothing other than the sacramental dimension of the Church. This sacramental dimension of the Church in its relationship with the liturgical actions done by the local Churches is explicitly described in SC 26. The sacramental dimension, which is the dialectical structure between the human and the divine realities, is the fundamental criterion for the liturgical reform. This means that the visible reality should express the invisible; the human reality should express fully the divine reality. For this reason, the liturgical texts and the rites, as the expressions of the human and 
visible realities, demanded a certain reform to help the people, as the subject of the liturgical action, to understand better the meaning of the liturgical celebration. This consideration can be found in SC 21. ${ }^{19}$ The use of the vernacular in the liturgy, especially in the Eucharist, is a key concrete step of the liturgical reform.

\section{THE VERNACULAR AND TRANSLA- TION IN LITURGIAM AUTHENTICAM}

This part is dedicated to examining the implementation of SC in LA regarding the understanding of the function of vernacular language and translation.

LA understands the translation of liturgical texts as an integral part of the liturgical renewal of Vatican II, just as did the preparation of liturgical books that followed the promulgation of SC. LA emphasizes two fundamental criteria in the process of the preparation of liturgical books, criteria presented as valid also for their translation into vernacular languages: they must be marked by sound doctrine (exact in wording) and free from ideological influence. ${ }^{20}$ These fundamental criteria impact the understanding of inculturation as a process that can be achieved through the process of translation. According to LA, real liturgical inculturation might be achieved only if the translation is able to maintain the unitary expression of the Roman Rite. ${ }^{21}$ This means that the translation of the liturgical texts should not introduce variation into the Roman Rite even though such variation would meet pastoral necessity and would respect the genius of the people of a particular culture and language. LA expects that any insertion will be done harmoniously into the Roman Rite.

The purpose of LA was to set new norms for the translation of liturgical texts in order to correct the omissions and errors which were perceived in the translations made on the basis of the previous instruction (Comme le Prévoit) and which were considered as obstacles for the authentic liturgy. The first attention given to fulfilling this purpose was the selection of the language to be used in liturgy. LA 10, 11, and 12 speak specifically about the criteria for the vernacular language to be used for liturgy. The vernacular language suited for liturgy, it asserts, should not be the language spoken spontaneously by the people, nor the language used for pastoral activity. A dialect cannot be chosen for liturgy because of its lack of stability. LA anticipates discord among the faithful regarding the choice of a certain local language for the use in the liturgy. LA 13 proposes the use of Latin for the liturgy rather than giving preference to one or another local language.

LA asserts that the vernacular liturgical language ought to be a refined or elevated form of the vernacular, not ever an ordinary vernacular. LA 47 uses the term "sacral vernacular". This conviction is based on making a distinction between the language for ordinary use and the language for liturgical use, the latter being also different from the language for pastoral use. LA asserts that the vernacular liturgical language might and should develop the vernacular language itself. This conviction insists on the literal translation of certain expressions of the ancient Church, as is described in LA 56. LA insists that an absolutely literal translation can foster development in the vernacular languages themselves. By setting new norms for the type of language suited for liturgical use, LA also assumes that the translation of liturgical texts done since Vatican II had been characterized by the use of "artificial language", as is described in LA 17. 
The conviction of LA that there should exist a vernacular liturgical language that is developed from and is above the ordinary vernacular might cause difficulty for the ordinary people. Insistence on the use of this literal translation method might well produce unintelligible texts. LA insists that this difficulty might be resolved by catechesis, as is described in LA 30. This solution proposed by LA seems contradictory with its own statement in LA 28. This latter number states that the task of the translators is to allow signs, images, and ritual actions to speak for themselves. This means that the translation made should be clear and understandable even without explanation. Without any doubt, this expectation can be fulfilled only if the language used for translating is the language of the people.

The possibility of the existence of a "sacral vernacular language" is presumed by the application of this "ratio translationis". ${ }^{22}$ This idea of the Congregation for Divine Worship and the Discipline of the Sacraments or Congregatio de Cultu Divino et Disciplina Sacramentorum (CDD) to provide a "ratio translationis" not only has changed the concept of collaboration between the Holy See and the Bishops' Conference but also has changed the understanding of the function of a vernacular language itself in the liturgy. In order to be as faithful as possible to the norms of LA, the CDD, after consultation with Bishops, can impose a "ratio translationis" for a given language into which the Latin texts are to be translated. The application of such a "ratio translationis", LA asserts, might develop the vernacular language itself. According to LA, this developed language is called "sacral vernacular".

Regarding the variety of vernacular languages, LA 85 makes the distinction be- tween six major languages (English, French, German, Italian, Portuguese, and Spanish) and the rest. This distinction is based on the consideration that these six are the languages most used in the world. Based on this reason, the CDD reserves to itself the right to involve itself directly in the preparation of the translation into these six languages, as is described in LA 76. LA 86 regulates the languages outside the six major languages. The examination by the CDD of the translation made into these non-major languages is to be done through one of the six major languages.

\section{CRITIQUES OF LITURGIAM AUTHENTI- CAM}

After describing the most important points of LA regarding the understanding of the vernacular language for liturgical use and regarding the translation of the liturgical texts, we will juxtapose those points with the understanding of SC on the same topics.

The first point to examine is the argument regarding the understanding and the choice of the vernacular language suited for the liturgy. LA clearly states that the vernacular language suited for liturgy is not the language spoken spontaneously by the people. It should be distinguished, as well, from the language used for pastoral activity. LA uses the term "sacral vernacular" to describe this vernacular suited for liturgical use. It is described as a refined or elevated form of the vernacular and not as a vernacular for ordinary use. LA believes that the "sacral vernacular" should develop the vernacular language itself. This development is made possible by the use of literal translation especially for the liturgical expressions found since the ancient Church. This development of a "sacral vernacular" is made 
possible also through of the application of a "ratio translationis". The CDD, after consultation with Bishops, can impose a "ratio translationis" for a given language into which the Latin texts are to be translated.

The concept and the choice of a vernacular language for liturgical use found in LA is hard to understand. The method of imposing "strange vocabularies" in the name of maintaining either unity of expression or faithfulness to the norms seems more to cause distortion than to help. This judgment is reasonable because the "ratio translationis" is imposed not by the local authority which de facto works directly with the translation but by the CDD. Clearly, it is impossible to have a better access to the genius of the people than does the local authority.

LA misunderstands the problem of faithfulness in translation and so proposes faulty criteria for translation. LA forgets that each language has its own way of thinking and its unique network of signs. LA respects Latin excessively while, at the same time, respecting not at all the vernacular languages. The fathers of the Council who supported the wider use of vernacular in the liturgy believed that the unity in the one faith is not equal to or guaranteed by uniformity. Faithfulness to the Church is not equal to faithfulness to Latin. LA ignores the basic function of language as a medium of communication. By positing the existence and priority of a "sacral language" LA excludes considering as important the intelligibility of the translation for uneducated people and children and creates for liturgical use a vernacular which excludes. LA risks losing the active participation of all people in the liturgy.

The second point to examine is the criteria and the purpose of the translation accord- ing to LA. LA emphasizes two fundamental criteria for translation: that it be marked by sound doctrine (exact in wording) and that it be free from ideological influence. Based on these criteria, LA states that the purpose of the translation is to maintain the unitary expression of the Roman Rite. This means that the process of the translation of the liturgical texts should not introduce variation into the Roman Rite. The promulgation of LA obliges the correction of the "omissions and errors" of the previous works of translation which were based on Comme le Prévoit. According to LA, these "omissions and errors" are considered to be obstacles to the authentic liturgy. LA assumes that the previous translations were characterized by the use of "artificial language".

The reasons used by LA, as mentioned above, indicate the generalization made by LA in its judgment of all previous translations and implies its mistrust of the processes done by the local ecclesiastical authorities. LA forgets that translation calls for a triple fidelity: fidelity to the original texts, to the given vernacular language, and to the intelligibility of the text by the people who use it. ${ }^{23}$ By not allowing the possibility of introducing variation into the translation, LA limits the possibility of bringing more benefit to the people through providing intelligible liturgical texts. By judging that the previous translations were full of "artificial language", LA forgets that the work of translation is also a work of culture. The work of translation cannot be simplified to an act of translating word by word. It cannot be simplified, either, into a problem which can and must be solved only be seeking approval.

The third point to examine are the arguments regarding the intelligibility of the translation and the status of Latin. As we have seen in the first point above, the be- 
lief in the existence of a "sacral vernacular" that is different from the ordinary vernacular might cause the problem of unintelligibility and anomaly in the translation of some Latin words or expressions. LA admits this possibility of unintelligibility and anomaly in some parts of the translation, especially because of the use of a literal translation method. LA proposes doing explanatory catechesis as a means of conveying the original meaning of the expressions that are considered strange or odd for the ordinary use. LA 30 insists that this difficulty can be resolved by liturgical catechesis. The proposal of catechesis as the solution for the difficulty of understanding the translation indicates the failure to craft liturgical texts which are or can be expressions of the genuine prayer of the Church.

It is interesting that LA considers Latin as the solution for resolving the difficulty of choosing a vernacular language in a society that has many different local languages. In particular cases, the choice of one or another local language might cause problems between the people in a diverse society. By proposing the use of Latin to solve this difficulty, LA confirms its belief in the superiority of Latin over the vernacular. LA appeals to the supporters of the exclusive use of Latin for the liturgy during the discussion on the formulation of the Constitution on the Sacred Liturgy. LA considers Latin superior because of its universality and immutability.

The argument mentioned above is disputable especially in the actual context of the Church. This position is not in accordance with the spirit of SC that emphasizes maintaining the intelligibility of the liturgical acts through intelligible rites and prayers, as is put forward in SC 48. LA seems to place little value on the intelligibility of the rites and prayers, giving preference, instead, to the uniformity factor. By claiming the superiority of Latin, LA also puts the vernacular languages on an inferior level.

The fourth point to examine is the policy of LA to make a distinction between the six major vernacular languages (English, French, German, Italian, Portuguese, and Spanish) and the rest. LA states that this distinction is based on the wider diffusion of these six languages. Regarding these six languages, LA also says that the CDD might involve itself directly in the work of translation done into these six vernacular languages. This distinction implies an examination process of the translation by the CDD. The examination of the translations outside these six major languages will be done through their fidelity to one of the six major languages.

The reason used by LA, that these six major languages are the most widely used by Catholics, is not correct. It is most obvious that these six are all Western languages. As an instrument of communication, every single language has an equal right to be the language of liturgical celebration.

The evaluation of the implementation of $\mathrm{SC}$ in LA underlines the importance of returning to the intentions of the Second Vatican Council as they are conveyed through $\mathrm{SC}$.

\section{SOME IMPORTANT POINTS TO CON- SIDER}

The use of the vernacular language in the liturgy and also the procedure of preparing the translation should be placed in the context of their function, namely, service to the people who celebrate the liturgy. This purpose is found in the expression of the second paragraph of SC 36: valde utilis 
apud populum. In other words, the liturgical reform of Vatican II desires the full and active participation of the people engaged in liturgical celebrations within their concrete community and their own language.

Regarding the utility of vernacular languages in the liturgy for the benefit of the people, as described by SC 36, we cannot forget two important relateddimensions: the community or congregation which celebrates and the intelligibility of the rites and prayers. The first dimension is described by SC 21 and the intelligibility of rites and prayers described by SC 48. Enrico Mazza has made an important comment aboutthe use of the words "communitatis propria" in SC 21: this Latin expression should be distinguished from the word "communiter." 4 The expression "communitatis propria" means "specific to the community"; the adverb "communiter" means "in common, commonly, generally, etc." From this clear and distinct difference, we can understand that SC means that a specific community's way of celebrating can be different from that of other communities. This radical understanding is best described in SC 48: "Itaque Ecclesia sollicitas curas eo intendit ne Christifideles huic fidei mysterio tamquam extranei vel muti spectatores intersint, sed per ritus et preces id bene intellegentes..."25 Only through intelligible rites and prayers can the people understand the mystery of the faith. From both numbers of SC, we can make the conclusion that it is fundamental that the Church should avoid the tendency that would render the people mute spectators in liturgical celebrations. Intelligible rites and prayers that are suited for the specific community which celebrates are indispensable.
The correct implementation of SC 36, including in regard to the collaboration between authorities in the preparation of liturgical translations, requires awareness of the concrete community of believers in its relation to the intelligibility of liturgical rites and prayers. The community and the liturgy are inseparable. This relationship characterizes liturgy and distinguishes liturgy from other activities of the Church. ${ }^{26}$ The nature of liturgy differentiates it from other basic activities of the Church. In the first place, liturgy involves the being together of like-minded people. It responds to a basic need of humans to be conscious of belonging to a community. From this we can understand that a worship service in which a person cannot feel or consider him or herself to be a member of that certain community is not a liturgy. The liturgy supports and deepens what is essential for the existence of the Church, an engagement of three partners: God, the individual, and the community. In order to maintain this partnership intact, there must be a real, active, and continuous communication.

The concrete community of worship and the intelligibility of the rites and prayers are the inseparable fundaments of the liturgical reform desired by Vatican II. There is a threat of returning to the condition before the Council when the liturgical language was not the language of the ordinary people (the concrete community). It has become a challenge to choose again norms for liturgical translation that accommodates these fundaments. The norms of the liturgical translation should secure the communicative potency of the liturgy. It is among the tasks of the Bishops' Conference to avoid the return of a clerical liturgical language. 
The liturgical translation is a work of culture. For accomplishing a liturgical translation as a work of culture, it is indispensable that experts in the local culture and local language work together with ecclesial experts. Only by this cooperation can the work of liturgical translation be "valde utilis apud populum". This cooperation makes possible the true inculturation of the Gospel among the people of God. The inculturation of the Gospel through the work of translation is possible if the work of translation is faithful also to the given vernacular language and not only to the Latin.

Liturgical translation as a means of inculturation of the Gospel is based on the mystery of the Incarnation itself. God manifests himself through the mystery of the Incarnation. Through this mystery, God reveals himself not in abstract form nor in an abstract time and space, but through the history of human salvation brought about in Jesus Christ. The pastoral spirit that animates the Constitution on the Sacred Liturgy allows the liturgy itself to be more genuine and authentic. An authentic liturgy means a liturgy in which the rites and the texts (and also the other signs) express clearly for the people the sacred reality, without causing any inordinate difficulties of understanding. This is the fundamental principle of the reform explicitly expressed in number 21 of SC. ${ }^{27}$

The liturgy and evangelization are inseparable. The fathers of the Council who came from the "new Churches" considered the intelligibility of the rites and prayers as a nec- essary means for transmitting the Christian faith to the people, especially those in mission lands. ${ }^{28}$ This means that the liturgy in the vernacular language is also a means of evangelization. This understanding assumes that the vernacular language used in the liturgy is not a language that excludes anyone. The language used in the liturgy cannot be the language only of the priest. It also cannot be the language only of the intellectuals. Rather, it must be the language of all, including those uneducated and the children. If the work of evangelization can and ought to be done through the liturgy, we have to return to understanding the function of the language as an instrument of communication, as a means of conveying a message. We have to put into question the existence of a "sacral vernacular" which would claim to be a "developed and refined form of the ordinary vernacular."

It is important that the Church not be trapped in an unnecessary and exaggerated procedure for preparing liturgical translations. Instead of bringing the liturgy to the people, the exaggerated procedure of preparing the translation now in place entrapes the liturgy in an argument about power. This argument is similar to what Pope Francis wrote about in his Apostolic Exhortation Evangelii Gaudium regarding the urgency of ecclesial renewal. He said that excessive centralization, rather than proving helpful, complicates the Church's life and her missionary outreach. ${ }^{29}$ 


\section{ENDNOTES}

Franciscus, "Litterae Apostolicae Motu Proprio Datae Magnum Principium," Libreria Editrice Vaticana (September 2017). https://w2.vatican.va/content/francesco/la/motu_proprio/documents/papa-francesco-motu-proprio_20170903 magnum-principium.html, (Access 22.01.2019).

2 Piero Marini, A Challenging Reform (Minnesota: Liturgical Press, 2007) xvii-xxi.

3 Cf. Ioannes XXIII "Constitutio Apostolica Veterum Sapientia,"Acta Apostolicae Sedis 54 (1962) 130.

4 Cf. Ioannes XXIII “Constitutio Apostolica Veterum Sapientia," 130 .

$5 \quad$ Cf. G. Settembri \& G. Venturi, "Uso della Lingua Volgare e Traduzione dei Testi Liturgici nel Dibattito Conciliare," Rivista Liturgica 92 (2005) 66-67.

6 Luigi Girardi, "Sacrosanctum Concilium", Commentario ai Documenti del Vaticano II, Vol.1, edd. S. Noceti-R. Repole (Bologna: EDB, 2014) 157.

7 Josef Andreas Jungmann, "Constitution on the Sacred Liturgy,"Commentary on the Documents of Vatican II, Vol.1, ed. H. Vorgrimler (London: Burns \& Oates Limited, 1967) 25-26.

8 Cf. Settembri-Venturi, art. cit., 58-59.

9 Cf. Settembri-Venturi, art. cit., 59.

10 Cf. Settembri-Venturi, art. cit., 58-59.

11 Cf. Settembri-Venturi, art. cit.,61-62.

12 Cf. Settembri-Venturi, art. cit., 58-59.

13 Henri Fesquet, Diario del Concilio (Milano: Mursia \& C., 1967) 52.

14 Settembri \& Venturi, art. cit., 69.

15 Cf. Pius XII, "Litterae Encyclicae Mediator Dei et Hominum," Acta Apostolicae Sedis 14 (1947) 521.

\section{BIBLIOGRAPHY}

Bonaccorso, Giorgio. Introduzione allo Studio della Liturgia (Padova: Edizione Messaggero, 1990).

Congregatio de Cultu Divino et Disciplina Sacramentorum, "Instructio Quinta ad Exsecutionem Constitutionis Concilii Vaticani Secundi de Sacra Liturgia Recte Ordinandam : Liturgiam Authenticam." Acta Apostolicae Sedis 93, (March 2001) 686-687.

Fesquet, Henri. Diario del Concilio (Milano: Mursia \& C.,1967).

Franciscus. "Adhortatio Apostolica: Evangelii Gaudium." Acta Apostolicae Sedis 105 (December 2013) 1019-1137.

Franciscus. "Litterae Apostolicae Motu Proprio Datae: Magnum Principium," Libreria Editrice Vaticana (September 2017). https://w2.vatican.va/content/francesco/ la/motu_proprio/documents/papa-francesco-motu-proprio_20170903_magnum-principium.html (äccess 22.01.2019).

Girardi, Luigi. "Sacrosanctum Concilium." Commentario ai Documenti del Vaticano II, Vol.1, edd. S. Noceti-R. Repole (Bologna: EDB, 2014) 131-161.
16 Enrico Mazza, "La Partecipazione Attiva alla Liturgia dalla Mediator Dei alla Sacrosanctum Concilium," Ecclesia Orans 30 (2013) 315-316.

17 Enrico Mazza, "La Partecipazione Attiva...,319-320.

18 Enrico Mazza, "La Partecipazione Attiva...,324.

19 Cf. Giorgio Bonaccorso, Introduzione allo Studio della Liturgia (Padova: Edizione Messaggero, 1990) 32-35.

20 Cf. Congregatio de Cultu Divino et Disciplina Sacramentorum, "Instructio Quinta ad Exsecutionem Constitutionis Concilii Vaticani Secundi de Sacra Liturgia Recte Ordinandam: Liturgiam Authenticam, Acta Apostolicae Sedis 93, Nr. 3(2001) 686-687.

21 Cf. Congregatio de Cultu Divino et Disciplina..., $\mathrm{Nr} 5$.

22 Cf. Congregatio de Cultu Divino et Disciplina..., Nr 9.

23 Cf. Cesare Giraudo, "Magnum Principium e l'Inculturazione Liturgica nel Solco del Concilio", La Civiltà Cattolica 4 (2017) 322.

24 Mazza, art. cit., 327.

25 Sacrosanctum Concilium Oecumenicum Vaticanum II, "Constitutio de Sacra Liturgia: Sacrosanctum Concilium, Acta Apostolicae Sedis 56, Nr. 48 (1964) 113.

26 Cf. Edward Kilmartin, Christian Liturgy (Kansas City: Sheed\& Ward 1988) 77-78.

27 Cipriano Vagaggini, "Lo Spirito della Costituzione sulla Liturgia”, Rivista Liturgica 1 (1964)32.

28 Cf. Keith Pecklers, Dynamic Equivalence (Minnesota: the Liturgical Press 2003) 183-186.

29 Cf. Franciscus, “Adhortatio Apostolica: Evangelii Gaudium”, Acta Apostolicae Sedis 105, Nr. 32 (2013) 1033-1034.

Giraudo, Cesare. "Magnum Principium e l'Inculturazione Liturgica nel Solco del Concilio.” La Civiltà Cattolica 4 (2017) 311-324.

Ioannes XXIII. "Constitutio Apostolica Veterum Sapientia." Acta Apostolicae Sedis 54, (1962) 129-135.

Jungmann, Josef Andreas. "Constitution on the Sacred Liturgy." Commentary on the Documents of Vatican II, Vol.1, edd. H. Vorgrimler (London: Burns \& Oates Limited, 1967) 1-26.

Kilmartin, Edward. Christian Liturgy (Kansas City: Sheed \& Ward, 1988).

Marini, Piero. A Challenging Reform. Realizing the Vision of the Liturgical Renewal (Minnesota: Liturgical Press, 2007).

Mazza, Enrico. "La Partecipazione Attiva alla Liturgia dalla Mediator Dei alla Sacrosanctum Concilium." Ecclesia Orans 30 (2013) 313-334.

Pecklers, Keith, Dynamic Equivalence (Minnesota: the Liturgical Press, 2003). 
Pius XII. "Litterae Encyclicae Mediator Dei et Hominum." Acta Apostolicae Sedis 14, (1947) 521-595.

Sacrosanctum Concilium Oecumenicum Vaticanum II. "Constitutio de Sacra Liturgia: Sacrosanctum Concilium." Acta Apostolicae Sedis 56, (1964) 97-134.
Settembri G. \& Venturi G. "Uso della Lingua Volgare e Traduzione dei Testi Liturgici nel Dibattito Conciliare." Rivista Liturgica 92, (2005) 49-72.

Vagaggini, Cipriano. "Lo Spirito della Costituzione sulla Liturgia." Rivista Liturgica 1, (1964) 5-49. 